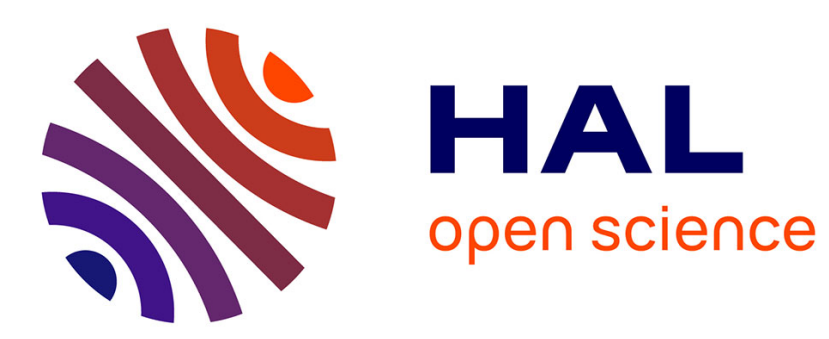

\title{
Kinetics of Al2O3-Scale Growth by Oxidation and Dissolution in Molten Silicate
}

\author{
Thomas Gheno, Brian Gleeson
}

\section{To cite this version:}

Thomas Gheno, Brian Gleeson. Kinetics of Al2O3-Scale Growth by Oxidation and Dissolution in Molten Silicate. Oxidation of Metals, 2017, 87 (3-4), pp.527-539. hal-01941933

\section{HAL Id: hal-01941933 \\ https://hal.science/hal-01941933}

Submitted on 2 Dec 2018

HAL is a multi-disciplinary open access archive for the deposit and dissemination of scientific research documents, whether they are published or not. The documents may come from teaching and research institutions in France or abroad, or from public or private research centers.
L'archive ouverte pluridisciplinaire HAL, est destinée au dépôt et à la diffusion de documents scientifiques de niveau recherche, publiés ou non, émanant des établissements d'enseignement et de recherche français ou étrangers, des laboratoires publics ou privés. 


\title{
Kinetics of $\mathrm{Al}_{2} \mathrm{O}_{3}$-scale growth by oxidation and dissolution in molten silicate
}

\author{
Thomas Gheno* (D) and Brian Gleeson \\ Department of Mechanical Engineering and Materials Science, \\ University of Pittsburgh, Pittsburgh PA 15261, USA \\ Email: thomas.gheno at gmail; bgleeson at pitt.edu
}

This is a post-peer-review, pre-copyedit version of an article published in

Oxidation of Metals. The final version is available online at:

https://doi.org/10.1007/s11085-016-9686-0

\begin{abstract}
During the high temperature oxidation of an alloy, the growth of a protective oxide scale selectively consumes one of the alloying elements. This can be accelerated if a molten deposit is present and dissolves the scale. The kinetics of $\mathrm{Al}_{2} \mathrm{O}_{3}$-scale growth and dissolution in $\mathrm{Na}$ silicate were studied by considering the $\mathrm{Al}$ mass balance at the alloy/scale and scale/silicate interfaces. The analysis was applied to a single-phase $\gamma-\mathrm{NiCoCrAlY}$ alloy exposed to a $\mathrm{SiO}_{2}-\mathrm{Na}_{2} \mathrm{SO}_{4}$ deposit at $1100{ }^{\circ} \mathrm{C}$, using an oxidation rate constant and effective $\mathrm{Al}$ diffusivity measured after deposit-free oxidation of the same alloy, and independent measurements of $\mathrm{Al}$ solubility and diffusivity in $\mathrm{Na}$ silicate. The simulated $\mathrm{Al}_{2} \mathrm{O}_{3}$-scale thickness and $\mathrm{Al}$ depletion profile matched well with the experimental data. The model was then used to assess $\mathrm{Al}_{2} \mathrm{O}_{3}$-scale failure on two alloys with particularly large $\mathrm{Cr}$ contents (27 and 35 at. \%), which underwent internal oxidation when exposed to the $\mathrm{SiO}_{2}-\mathrm{Na}_{2} \mathrm{SO}_{4}$ deposit.
\end{abstract}

Keywords Oxide growth; Selective oxidation; Silicate deposit

\section{Introduction}

Alloys and coatings used at high temperatures withstand corrosion through the formation of slow-growing, compact and adherent oxide scales, e.g., $\mathrm{Cr}_{2} \mathrm{O}_{3}$ or $\mathrm{Al}_{2} \mathrm{O}_{3}$. Such a protective scaling behavior may be challenged if a deposit condenses on the component surface and reacts with the thermally grown oxide. Indeed, at steadystate, protective scale growth is typically limited by solid-state diffusion in the oxide, and proceeds at a rate inversely proportional to the scale thickness, i.e.,

$$
\frac{\mathrm{d} X}{\mathrm{~d} t}=\frac{k_{\mathrm{p}}}{X}
$$

where $X$ is the thickness, $t$ the time and $k_{\mathrm{p}}$ the parabolic constant. Any process consuming the scale would result in an increased oxidation rate. In recent studies [1-3], we showed that $\mathrm{Al}_{2} \mathrm{O}_{3}$-scale forming NiCoCrAlY compositions in air were susceptible to accelerated corrosion in the presence of oxide-sulfate deposits. Two modes of attack were identified, which involved $\mathrm{Al}_{2} \mathrm{O}_{3}$ reaction with $\mathrm{CaO}$ to form $\mathrm{Ca}$ aluminates, and $\mathrm{Al}_{2} \mathrm{O}_{3}$ dissolution in molten $\mathrm{Na}$ silicate. Both processes cause an increased $\mathrm{Al}$ consumption and can lead to internal oxidation if the $\mathrm{Al}$ flux required for the scale to grow exceeds that available from the alloy. Thus $\mathrm{Al}_{2} \mathrm{O}_{3}$-scale failure is expected to occur in alloys with an $\mathrm{Al}$ concentration below a certain threshold. The conditions for this are analyzed in the following.

\footnotetext{
${ }^{*}$ now at DEN-Service de la Corrosion et du Comportement des Matériaux dans leur Environnement, CEA, Université Paris-Saclay, 91191 Gif-sur-Yvette, France
} 


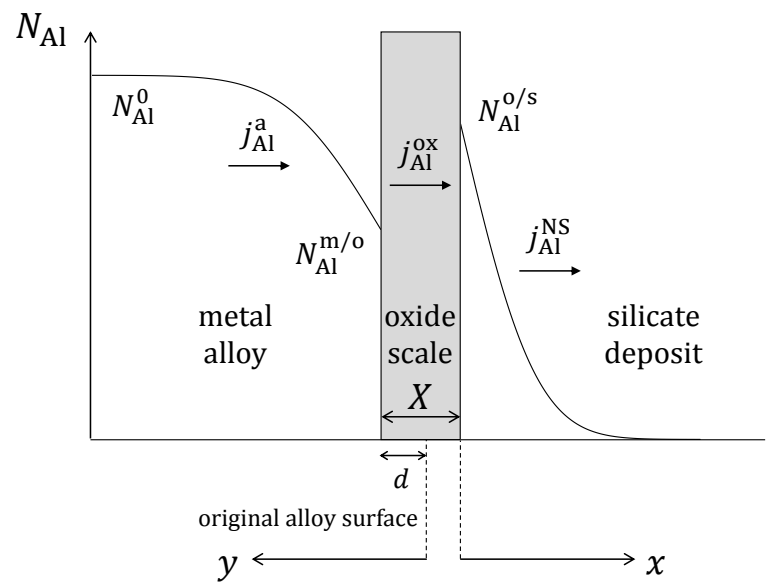

Figure 1: Schematic Al concentration profiles developed in a system where an $\mathrm{Al}_{2} \mathrm{O}_{3}$ scale is formed by oxidation of an alloy and consumed by dissolution in a molten silicate.

\section{Modeling}

The consequences of $\mathrm{Al}_{2} \mathrm{O}_{3}$ dissolution in molten Na silicate (NS) are evaluated by modeling oxide growth kinetics in a manner similar to that adopted in the study of solid-state reaction with $\mathrm{CaO}$ [1]. A thickening rate law is first determined by adding the contribution of oxide dissolution to that of oxide formation, in a regime where dissolution is limited by diffusion in the silicate. The $\mathrm{Al}$ mass balance is then derived by considering the $\mathrm{Al}$ flux in the alloy, the oxide scale and the silicate. The situation is illustrated in Fig. 1.

The dissolution rate of $\mathrm{Al}_{2} \mathrm{O}_{3}$ is related to the $\mathrm{Al}$ flux entering the silicate, $\left(J_{\mathrm{Al}}^{\mathrm{NS}}\right)_{x=0}$, via

$$
\frac{(\mathrm{d} X)_{\mathrm{d}}}{\mathrm{d} t}=-\frac{V_{\mathrm{Al}_{2} \mathrm{O}_{3}}}{2}\left(J_{\mathrm{Al}}^{\mathrm{NS}}\right)_{x=0}
$$

where $V_{\mathrm{Al}_{2} \mathrm{O}_{3}}$ is the molar volume of $\mathrm{Al}_{2} \mathrm{O}_{3}$ (the factor of $1 / 2$ on the right-hand side accounts for the fact that there are two moles of $\mathrm{Al}$ per mole of $\mathrm{Al}_{2} \mathrm{O}_{3}$ ). This flux is calculated by solving the diffusion equation in the silicate. Assuming the molar volume of the silicate, $V_{\mathrm{NS}}$, is independent of its composition, Fick's law may be written as

$$
J_{\mathrm{Al}}^{\mathrm{NS}}=-\frac{D_{\mathrm{Al}}^{\mathrm{NS}}}{V_{\mathrm{NS}}} \frac{\partial N_{\mathrm{Al}}^{\mathrm{NS}}}{\partial x}
$$

with $D_{\mathrm{Al}}^{\mathrm{NS}}$ and $N_{\mathrm{Al}}^{\mathrm{NS}}$ the diffusion coefficient and mole fraction of $\mathrm{Al}$ in NS, respectively. Further assuming that $D_{\mathrm{Al}}^{\mathrm{NS}}$ is constant, the time-dependent diffusion equation is

$$
\frac{\partial N_{\mathrm{Al}}^{\mathrm{NS}}}{\partial t}=D_{\mathrm{Al}}^{\mathrm{NS}} \frac{\partial^{2} N_{\mathrm{Al}}^{\mathrm{NS}}}{\partial x^{2}}
$$

At steady-state, $N_{\mathrm{Al}}^{\mathrm{NS}}$ at the $\mathrm{Al}_{2} \mathrm{O}_{3} / \mathrm{NS}$ interface, $N_{\mathrm{Al}}^{\mathrm{o} / \mathrm{s}}$, is constant and equal to the $\mathrm{Al}$ solubility in NS. Equation (3) is then solved to yield [4]

$$
N_{\mathrm{Al}}^{\mathrm{NS}}(x, t)=N_{\mathrm{Al}}^{\mathrm{o} / \mathrm{s}} \operatorname{erfc}\left(\frac{x}{2 \sqrt{D_{\mathrm{Al}}^{\mathrm{NS}} t}}\right)
$$


It follows that at the $\mathrm{Al}_{2} \mathrm{O}_{3} / \mathrm{NS}$ interface,

$$
\left(\frac{\partial N_{\mathrm{Al}}^{\mathrm{NS}}}{\partial x}\right)_{x=0}=-\frac{N_{\mathrm{Al}}^{\mathrm{o} / \mathrm{s}}}{\sqrt{\pi D_{\mathrm{Al}}^{\mathrm{NS}} t}}
$$

which is combined with Eqs. (2) and (3) to give

$$
\frac{(\mathrm{d} X)_{\mathrm{d}}}{\mathrm{d} t}=-\frac{1}{2} \frac{V_{\mathrm{Al}_{2} \mathrm{O}_{3}}}{V_{\mathrm{NS}}} N_{\mathrm{Al}}^{\mathrm{o} / \mathrm{s}} \sqrt{\frac{D_{\mathrm{Al}}^{\mathrm{NS}}}{\pi t}}
$$

The net $\mathrm{Al}_{2} \mathrm{O}_{3}$ growth is obtained by adding the production rate, Eq. (1), and the dissolution rate, Eq. (7):

$$
\frac{\mathrm{d} X}{\mathrm{~d} t}=\frac{k_{\mathrm{p}}}{X}-\frac{k_{\mathrm{d}}}{\sqrt{t}}
$$

where the dissolution constant $k_{\mathrm{d}}$ is

$$
k_{\mathrm{d}}=\frac{1}{2} \frac{V_{\mathrm{Al}_{2} \mathrm{O}_{3}}}{V_{\mathrm{NS}}} N_{\mathrm{Al}}^{\mathrm{o} / \mathrm{s}} \sqrt{\frac{D_{\mathrm{Al}}^{\mathrm{NS}}}{\pi}}
$$

Equation (8) is analogous to that obtained for $\mathrm{Al}_{2} \mathrm{O}_{3}$ reaction with $\mathrm{CaO}$ [1]. Considering that $X(t=0)=0$, it is solved to yield the new rate law

$$
\begin{gathered}
X^{2}=2 k^{\prime} t \\
k^{\prime}=k_{\mathrm{d}}^{2}+k_{\mathrm{p}}-k_{\mathrm{d}} \sqrt{k_{\mathrm{d}}^{2}+2 k_{\mathrm{p}}}
\end{gathered}
$$

The simple form of Eq. (10) derives from the choice of parabolic kinetics to describe intrinsic scale growth: Eq. (1) was used with the underlying assumptions that scale growth was limited by diffusion in the scale from the start, and that the oxide diffusivity was constant with time. Strictly speaking, the requirement of a finite reaction rate at $t=0$ involves the existence of a preexisting scale; this and other transient effects would generate constant and linear terms in the rate law [5]. Furthermore, $\mathrm{Al}_{2} \mathrm{O}_{3}$-scale growth is typically limited by grain boundary diffusion, and oxide grain growth would lead to sub-parabolic kinetics $[6,7]$. Nonetheless, results inferred from the assumption of parabolic kinetics from $t=0$ are valuable owing to their simplicity, and often prove useful in practice.

Within this assumption, $\mathrm{Al}_{2} \mathrm{O}_{3}$ growth also follows parabolic kinetics in the oxidation-dissolution regime, with a rate constant given by Eq. (11). This is now used to calculate the $\mathrm{Al}$ concentration at the metal/oxide interface, $N_{\mathrm{Al}}^{\mathrm{m} / \mathrm{o}}$, according to Wagner's analysis [8]. The latter was developed for binary alloys and used a constant interdiffusion coefficient in the alloy. The case of n-element alloys, $n>2$, is more complex, as interdiffusion is described with a set of $(n-1)^{2}$ independent coefficients. For the sake of simplicity, the present analysis considers instead a unique, effective $\mathrm{Al}$ diffusion coefficient in any given (single-phase) NiCoCrAlY alloy, denoted as $D_{\mathrm{Al}}^{\mathrm{a}}$. As shown later, the approach is useful if such an effective coefficient can be measured in the same alloy after oxidation with no deposit. $N_{\mathrm{Al}}^{\mathrm{m} / \mathrm{o}}$ is then given by $[8]$

$$
\frac{N_{\mathrm{Al}}^{0}-N_{\mathrm{Al}}^{\mathrm{m} / \mathrm{o}}}{1-N_{\mathrm{Al}}^{\mathrm{m} / \mathrm{o}}}=F\left(\sqrt{\frac{1}{2} \frac{k_{\mathrm{c}}}{D_{\mathrm{Al}}^{\mathrm{a}}}}\right)
$$


where $F$ is the auxiliary function defined by $F(u)=\sqrt{\pi} u(1-\operatorname{erf} u) \exp \left(u^{2}\right)$ and $k_{\mathrm{c}}$ the parabolic constant for metal recession. The latter is defined as

$$
d^{2}=2 k_{\mathrm{c}} t
$$

where $d$ is the depth of the metal/oxide interface relative to the original alloy surface.

In the absence of dissolution, the mass balance for the $\mathrm{Al}$ contained in the oxide scale is given as

$$
\frac{2 X}{V_{\mathrm{Al}_{2} \mathrm{O}_{3}}}=\frac{d}{V_{\mathrm{a}}}
$$

with $V_{\text {a }}$ the molar volume of the alloy. This yields

$$
k_{\mathrm{c}}=\left(\frac{2 V_{\mathrm{a}}}{V_{\mathrm{Al}_{2} \mathrm{O}_{3}}}\right)^{2} k_{\mathrm{p}}
$$

When the $\mathrm{Al}_{2} \mathrm{O}_{3}$ dissolves in NS, the mass balance in Eq. (14) becomes

$$
\frac{2 X}{V_{\mathrm{Al}_{2} \mathrm{O}_{3}}}+n_{\mathrm{Al}}^{\mathrm{NS}}=\frac{d}{V_{\mathrm{a}}}
$$

where $n_{\mathrm{Al}}^{\mathrm{NS}}$ is the amount of $\mathrm{Al}$ in the silicate per unit surface area, i.e., the accumulated flux of $\mathrm{Al}$ into the silicate over time. Combining Eqs. (3) and (6), the $\mathrm{Al}$ flux at the $\mathrm{Al}_{2} \mathrm{O}_{3} / \mathrm{NS}$ interface can be written as

$$
\left(J_{\mathrm{Al}}^{\mathrm{NS}}\right)_{x=0}=\frac{N_{\mathrm{Al}}^{\mathrm{o} / \mathrm{s}}}{V_{\mathrm{NS}}} \sqrt{\frac{D_{\mathrm{Al}}^{\mathrm{NS}}}{\pi t}}
$$

which yields [4]

$$
n_{\mathrm{Al}}^{\mathrm{NS}}=\int_{0}^{t} J_{\mathrm{Al}}^{\mathrm{NS}}(t) \mathrm{d} t=2 \frac{N_{\mathrm{Al}}^{\mathrm{o} / \mathrm{s}}}{V_{\mathrm{NS}}} \sqrt{\frac{D_{\mathrm{Al}}^{\mathrm{NS}} t}{\pi}}
$$

Using the definitions of $k_{\mathrm{d}}$ and $k^{\prime}, n_{\mathrm{Al}}^{\mathrm{NS}}$ can be written as

$$
n_{\mathrm{Al}}^{\mathrm{NS}}=\frac{2 X k_{\mathrm{d}}}{V_{\mathrm{Al}_{2} \mathrm{O}_{3}}} \sqrt{\frac{2}{k^{\prime}}}
$$

This is introduced into Eq. (16) to give

$$
\frac{2 X}{V_{\mathrm{Al}_{2} \mathrm{O}_{3}}}\left(1+k_{\mathrm{d}} \sqrt{\frac{2}{k^{\prime}}}\right)=\frac{d}{V_{\mathrm{a}}}
$$

Noting that, by definition, $X=\sqrt{2 k^{\prime} t}$ is a solution of Eq. (8), $k^{\prime}$ verifies

$$
\frac{k^{\prime}}{\sqrt{2 k^{\prime}}}=\frac{k_{\mathrm{p}}}{\sqrt{2 k^{\prime}}}-k_{\mathrm{d}}
$$

The latter can be rearranged to give $1+k_{\mathrm{d}} \sqrt{\frac{2}{k^{\prime}}}=\frac{k_{\mathrm{p}}}{k^{\prime}}$. Substituting into Eq. (20) yields

$$
\frac{2 X}{V_{\mathrm{Al}_{2} \mathrm{O}_{3}}} \frac{k_{\mathrm{p}}}{k^{\prime}}=\frac{d}{V_{\mathrm{a}}}
$$


Equation (22) together with the definition of $k^{\prime}$ and $k_{\mathrm{c}}$, Eqs. (11) and (13), respectively, provide the following expression for $k_{\mathrm{c}}$

$$
k_{\mathrm{c}}=\left(\frac{2 V_{\mathrm{a}}}{V_{\mathrm{Al}_{2} \mathrm{O}_{3}}}\right)^{2} \frac{k_{\mathrm{p}}^{2}}{k^{\prime}}
$$

Thus changing from intrinsic oxidation, Eq. (15), to oxidation-dissolution, Eq. (23), amounts to replacing $k_{\mathrm{p}}$ by $k_{\mathrm{p}}^{2} / k^{\prime}$ when evaluating $\mathrm{Al}$ consumption. The same expression was arrived at in the case of solid-state reaction with $\mathrm{CaO}$ [1] - the analogy reflects the fact that both $\mathrm{Ca}$ aluminate growth and $\mathrm{Al}$ diffusion in NS are diffusion-controlled processes.

\section{$3 \quad$ Materials and experiments}

Experimental data were obtained from NiCoCrAlY alloys, based on the fcc-A1 solid solution $\gamma-(\mathrm{Ni}, \mathrm{Co})$ and the $\mathrm{B} 2$ compound $\beta-(\mathrm{Ni}, \mathrm{Co}) \mathrm{Al}$, reacted with and without $\mathrm{SiO}_{2}-10$ wt. $\% \mathrm{Na}_{2} \mathrm{SO}_{4}$ deposits in $\mathrm{CO}_{2}-20 \mathrm{H}_{2} \mathrm{O}-1.6 \mathrm{O}_{2}$ at $1100{ }^{\circ} \mathrm{C}$. The experimental procedure is detailed in Ref. [2]. Briefly, $50 \mathrm{~h}$ isothermal corrosion experiments were conducted in a tube furnace under flowing gas, using cast alloys. The gas flow rate was $100 \mathrm{ml} / \mathrm{min}$, with a linear velocity of $2 \mathrm{~mm} / \mathrm{s}$ at $1100{ }^{\circ} \mathrm{C}$, and a total pressure slightly over $1 \mathrm{~atm}$. The alloys were cast and vacuum-annealed at the Materials Preparation Center of the Ames Laboratory [9]. Prior to exposure, $1 \mathrm{~mm}$ thick specimens were ground using $\mathrm{SiC}$ paper to a P1200-grit finish. Laboratory-grade powders were ground and applied as an ethanol-based slurry, producing $30 \pm 5$ $\mathrm{mg} / \mathrm{cm}^{2}$ deposits after evaporation of the ethanol. Sodium was applied as a sulfate, but it reacted with $\mathrm{SiO}_{2}$ to form a molten silicate in the S-free gas at $1100{ }^{\circ} \mathrm{C}$.

At the end of the $50 \mathrm{~h}$ experiments, metallographic cross-sections were prepared and analyzed by electron probe microanalysis (EPMA) using a JEOL JXA 8530F. Measured intensities were processed via a built-in ZAF calibration procedure, using pure metals as standards. Two alloy composition profiles were recorded below the $\mathrm{Al}_{2} \mathrm{O}_{3}$ scale in each specimen.

\section{Results and discussion}

Alloy composition effects were studied by varying the $\beta$ phase fraction and the $\mathrm{Cr}$ content. In general, $\beta$-rich alloys were immune to the Na silicate (NS), and formed external $\mathrm{Al}_{2} \mathrm{O}_{3}$ scales, while some $\gamma$-rich alloys suffered internal oxidation [2]. The situation of exclusive external scaling will be considered to evaluate the validity of the oxidation-dissolution analysis. The effects of alloy composition on scale failure will be discussed subsequently.

First, the dissolution constant $k_{\mathrm{d}}$ is determined from the solubility and diffusivity of $\mathrm{Al}$ in the silicate, as well as its molar volume. Analysis by SEM-EDS of NS deposits left after corrosion experiments gave a $\mathrm{Na}_{2} \mathrm{O}$ fraction of 15 mol. \%, close to the liquid composition expected at $1100{ }^{\circ} \mathrm{C}$ [10]. This was used with density and expansivity measurements of $\mathrm{Na}_{2} \mathrm{O}-\mathrm{SiO}_{2}$ solutions [11] to provide $V_{\mathrm{NS}}=27.5$ $\mathrm{cm}^{3} / \mathrm{mol}$ at $1100{ }^{\circ} \mathrm{C}$. The influence of dissolved $\mathrm{Al}$ on the molar volume, although possibly significant, is neglected due to lack of adequate data. In corrosion experiments, the NS thickness atop the specimens was found to be variable, and sometimes 


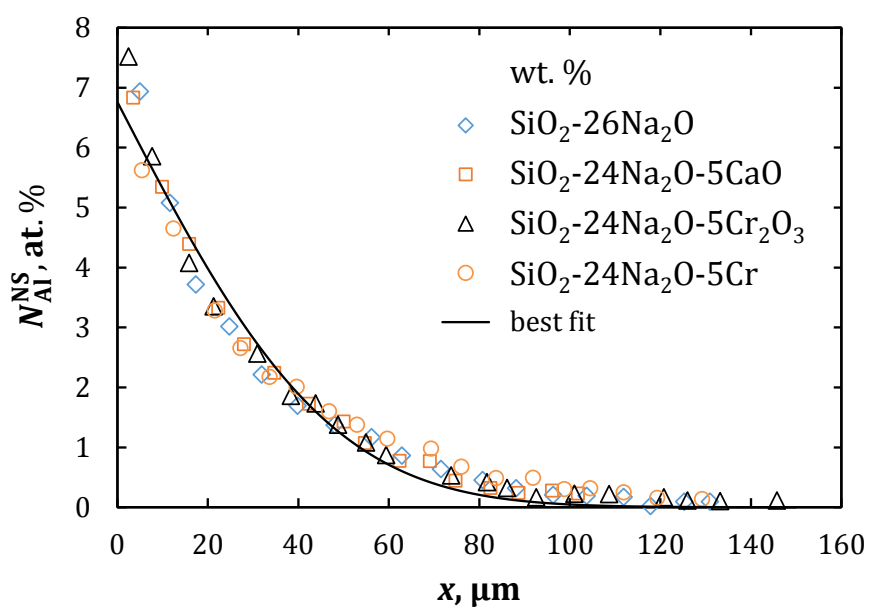

Figure 2: Aluminum concentration profiles measured by SEM-EDS from $\mathrm{Al}_{2} \mathrm{O}_{3}$ crucibles dissolving in silicate mixtures, after $4 \mathrm{~h}$ annealing at $1100{ }^{\circ} \mathrm{C}$. The best fit of Eq. (5) to the experimental data is showed by a solid line.

Table 1: Parameters used in the calculation of the $\mathrm{Al}_{2} \mathrm{O}_{3}$ dissolution constant, $k_{\mathrm{d}}$, via Eq. (9). The $\mathrm{Al}$ solubility and diffusivity in Na silicate, $N_{\mathrm{Al}}^{\mathrm{o} / \mathrm{s}}$ and $D_{\mathrm{Al}}^{\mathrm{NS}}$, were adjusted by fitting Eq. (5) to $\mathrm{Al}$ concentration profiles measured after $\mathrm{Al}_{2} \mathrm{O}_{3}$ dissolution in $\mathrm{Na}$ silicate (Fig. 2).

\begin{tabular}{lc}
\hline$V_{\mathrm{NS}}\left(\mathrm{cm}^{3} / \mathrm{mol}\right)[11]$ & 27.5 \\
$V_{\mathrm{Al}_{2} \mathrm{O}_{3}}\left(\mathrm{~cm}^{3} / \mathrm{mol}\right)[12]$ & 25.6 \\
$N_{\mathrm{Al}}^{\mathrm{O} / \mathrm{s}}(\mathrm{at.} \%)$ & 6.8 \\
$D_{\mathrm{Al}}^{\mathrm{NS}}\left(\mathrm{cm}^{2} / \mathrm{s}\right)$ & $4.8 \times 10^{-10}$ \\
$k_{\mathrm{d}}\left(\mathrm{cm}^{2} / \mathrm{s}\right)$ & $3.9 \times 10^{-7}$ \\
\hline
\end{tabular}

no greater than the diffusion length of $\mathrm{Al}$, such that the $\mathrm{Al}$ concentration reached a plateau (larger than 0). It is noted that such an $\mathrm{Al}$ accumulation in the silicate reduces the $\mathrm{Al}$ flux, and thus locally affects the $\mathrm{Al}_{2} \mathrm{O}_{3}$ dissolution and thickening rates. In order to obtain reliable values of solubility and diffusivity in the general case of a thick NS deposit, some $\mathrm{Na}_{2} \mathrm{Si}_{3} \mathrm{O}_{7}$ powder was annealed in an $\mathrm{Al}_{2} \mathrm{O}_{3}$ crucible, with no metal specimen, for $4 \mathrm{~h}$ at $1100{ }^{\circ} \mathrm{C}$. The $\mathrm{Al}$ concentration profile resulting from the dissolution of the $\mathrm{Al}_{2} \mathrm{O}_{3}$ crucible was measured by SEM-EDS (Fig. 2). Values of $N_{\mathrm{Al}}^{\mathrm{o} / \mathrm{s}}$ and $D_{\mathrm{Al}}^{\mathrm{NS}}$ obtained by fitting Eq. (5) to the profile using a least-squares method are given in Table 1 , along with the resulting $k_{\mathrm{d}}$ (Eq. (9)). A slight variance is observed in Fig. 2 between the shape of the NS fitted profile and the experimental data, likely due to variations of $V_{\mathrm{NS}}$ or $D_{\mathrm{Al}}^{\mathrm{NS}}$ with the Al fraction.

\subsection{Evaluation of the model: external $\mathrm{Al}_{2} \mathrm{O}_{3}$-scale growth}

The analysis of oxidation-dissolution kinetics is now applied to $\mathrm{Ni}-28 \mathrm{Co}-19 \mathrm{Cr}-11 \mathrm{Al}-$ $0.1 \mathrm{Y}$ (at. \%), a single-phase $\gamma$ alloy at $1100{ }^{\circ} \mathrm{C}$, which maintained exclusive $\mathrm{Al}_{2} \mathrm{O}_{3^{-}}$ scale formation (Fig. 3). The oxidation constant $k_{\mathrm{p}}$ was determined from the average scale thickness measured after a $50 \mathrm{~h}$ oxidation experiment conducted in the same 

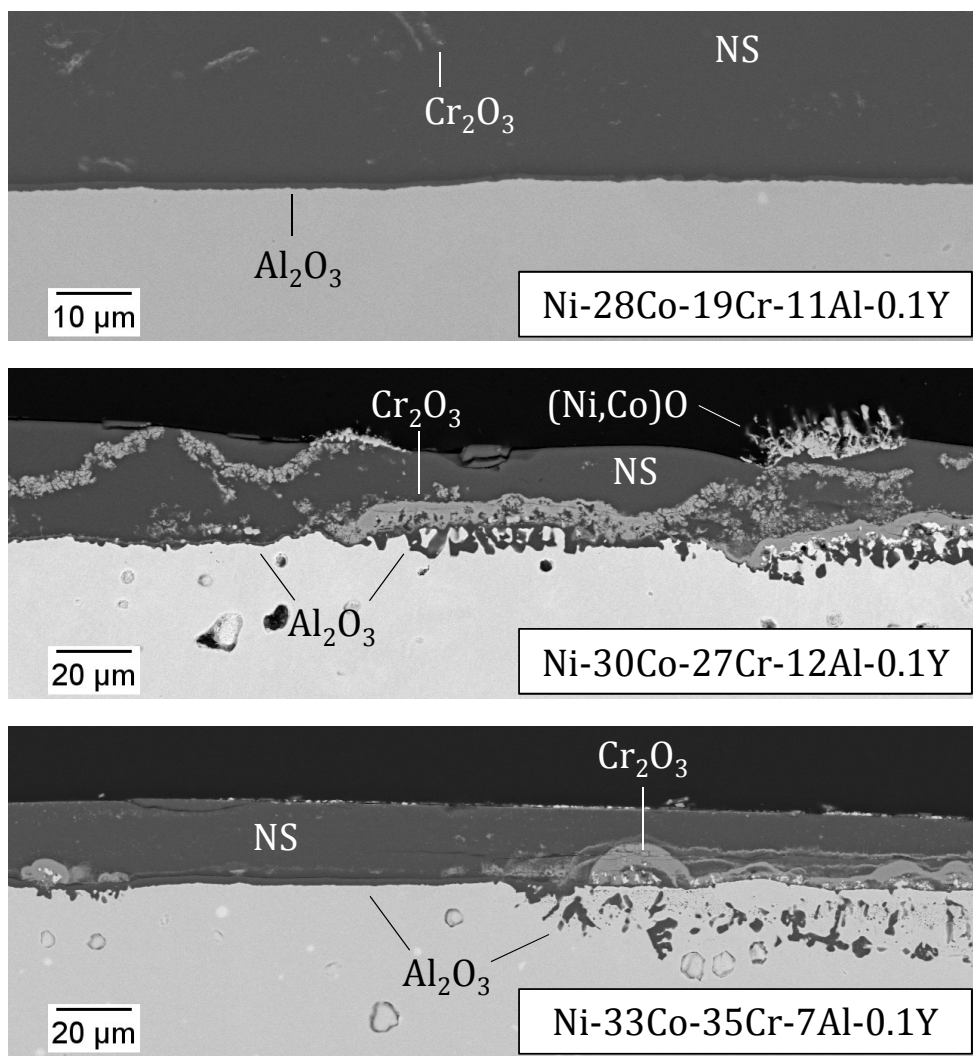

Figure 3: Cross-section micrographs of the corrosion products formed after $50 \mathrm{~h}$ exposure to $\mathrm{SiO}_{2}-10 \mathrm{Na}_{2} \mathrm{SO}_{4}$ in $\mathrm{CO}_{2}-20 \mathrm{H}_{2} \mathrm{O}-1.6 \mathrm{O}_{2}$ at $1100{ }^{\circ} \mathrm{C}$. The $\mathrm{Ni}-28 \mathrm{Co}-19 \mathrm{Cr}-11 \mathrm{Al}-0.1 \mathrm{Y}(\gamma)$ alloy maintained an external $\mathrm{Al}_{2} \mathrm{O}_{3}$ scale, while $\mathrm{Ni}-30 \mathrm{Co}-27 \mathrm{Cr}-12 \mathrm{Al}-0.1 \mathrm{Y}(\gamma-13$ vol. $\% \beta)$ and $\mathrm{Ni}-33 \mathrm{Co}-35 \mathrm{Cr}-7 \mathrm{Al}-0.1 \mathrm{Y}(\gamma)$ locally underwent internal oxidation (alloy compositions in at. \%).

conditions as the $\mathrm{SiO}_{2}-\mathrm{Na}_{2} \mathrm{SO}_{4}$ exposure, but with no deposit. It is recognized that thickness measurements after a single reaction time provide no indication as to the time-dependence of the oxidation process. This aspect was not studied experimentally. Rather, as indicated in Section 2, intrinsic scaling kinetics were assumed to be parabolic throughout the analysis. The $k_{\mathrm{p}}$ value was thus used with Eq. (11) to obtain $k^{\prime}$, which in turn was used to calculate the expected $\mathrm{Al}_{2} \mathrm{O}_{3}$ thickness in the oxidation-dissolution regime via Eq. (10). These parameters are summarized in Table 2. The average thickness measured in $\mathrm{Ni}-28 \mathrm{Co}-19 \mathrm{Cr}-11 \mathrm{Al}-0.1 \mathrm{Y}$ after exposure to $\mathrm{SiO}_{2}-\mathrm{Na}_{2} \mathrm{SO}_{4}, 0.8 \pm 0.1 \mu \mathrm{m}$, is in good agreement with the calculated value of $1.0 \mu \mathrm{m}$.

The analysis is further evaluated by considering the effect of $\mathrm{Al}_{2} \mathrm{O}_{3}$ dissolution on $\mathrm{Al}$ consumption in the alloy: the interfacial $\mathrm{Al}$ concentration is calculated from the constants $k_{\mathrm{p}}$ and $k^{\prime}$, via Eqs. (12) and (23), and compared with $\mathrm{Al}$ concentration profiles measured by EPMA below the $\mathrm{Al}_{2} \mathrm{O}_{3}$ scale after the $\mathrm{SiO}_{2}-\mathrm{Na}_{2} \mathrm{SO}_{4}$ exposure. Equation (12) requires an effective diffusion coefficient for $\mathrm{Al}$ in the alloy. In the absence of adequate literature data, $D_{\mathrm{Al}}^{\mathrm{NS}}$ is obtained from the depletion profiles measured after the deposit-free oxidation of the same alloy. The expression derived by Wagner for the depletion profile developed upon a oxidation of a binary alloy [8] 
Table 2: $\mathrm{Al}_{2} \mathrm{O}_{3}$-scale thicknesses and thickening constants in the oxidation and oxidationdissolution regimes, corresponding to $50 \mathrm{~h}$ deposit-free and $\mathrm{SiO}_{2}-\mathrm{Na}_{2} \mathrm{SO}_{4}$ deposit exposures at $1100{ }^{\circ} \mathrm{C}$, respectively.

\begin{tabular}{lccc}
\hline $\begin{array}{l}\text { Alloy composition, at. } \% \\
\left.\text { (phases at } 1100{ }^{\circ} \mathrm{C}\right)\end{array}$ & $\begin{array}{c}\mathrm{Ni}-28 \mathrm{Co}-19 \mathrm{Cr} \\
-11 \mathrm{Al}-0.1 \mathrm{Y}(\gamma)\end{array}$ & $\begin{array}{c}\mathrm{Ni}-33 \mathrm{Co}-35 \mathrm{Cr} \\
-7 \mathrm{Al}-0.1 \mathrm{Y}(\gamma)\end{array}$ & $\begin{array}{c}\mathrm{Ni}-30 \mathrm{Co}-27 \mathrm{Cr} \\
-12 \mathrm{Al}-0.1 \mathrm{Y}(\gamma-\beta)\end{array}$ \\
\hline No deposit & & & \\
$X(\mu \mathrm{m})$, measured & $2.0 \pm 0.4$ & $1.8 \pm 0.3$ & $1.9 \pm 0.4$ \\
$k_{\mathrm{p}}\left(\mathrm{cm}^{2} / \mathrm{s}\right)$ & $1.2 \times 10^{-13}$ & $9.0 \times 10^{-14}$ & $1.0 \times 10^{-13}$ \\
$D_{\mathrm{Al}}^{\mathrm{a}}\left(\mathrm{cm}^{2} / \mathrm{s}\right)$ & $1.2 \times 10^{-10}$ & $5.9 \times 10^{-11}$ & \\
$\mathrm{SiO}_{2}-\mathrm{Na}_{2} \mathrm{SO}_{4}$ deposits & & & \\
$k^{\prime}\left(\mathrm{cm}^{2} / \mathrm{s}\right)$, Eq. $(11)$ & $2.7 \times 10^{-14}$ & $1.8 \times 10^{-14}$ & $2.1 \times 10^{-14}$ \\
$X(\mu \mathrm{m})$, calculated & 1.0 & 0.8 & 0.9 \\
$X(\mu \mathrm{m})$, measured & $0.8 \pm 0.1$ & $\mathrm{n} / \mathrm{a}^{\mathrm{a}}$ & $\mathrm{n} / \mathrm{a}^{\mathrm{a}}$ \\
\hline
\end{tabular}

${ }^{\mathrm{a}}$ Local variations were too important for a meaningful average to be determined.

is used with the effective coefficient $D_{\mathrm{Al}}^{\mathrm{NS}}$ :

$$
\frac{N_{\mathrm{Al}}^{\mathrm{a}}(y, t)-N_{\mathrm{Al}}^{\mathrm{m} / \mathrm{o}}}{N_{\mathrm{Al}}^{0}-N_{\mathrm{Al}}^{\mathrm{m} / \mathrm{o}}}=\frac{\operatorname{erf}\left(\frac{y}{2 \sqrt{D_{\mathrm{Al}}^{\mathrm{a}} t}}\right)-\operatorname{erf}\left(\sqrt{\frac{k_{\mathrm{c}}}{2 D_{\mathrm{Al}}^{\mathrm{a}}}}\right)}{1-\operatorname{erf}\left(\sqrt{\frac{k_{\mathrm{c}}}{2 D_{\mathrm{Al}}^{\mathrm{a}}}}\right)}
$$

In Eq. $(24), N_{\mathrm{Al}}^{\mathrm{a}}(y, t), N_{\mathrm{Al}}^{\mathrm{m} / \mathrm{o}}$ and $N_{\mathrm{Al}}^{0}$ are the $\mathrm{Al}$ atom fractions at a distance $y$ from the original metal surface, at the metal/oxide interface and in the bulk alloy, respectively (see Fig. 1). In the absence of a deposit, $N_{\mathrm{Al}}^{\mathrm{m} / \mathrm{o}}$ and $k_{\mathrm{c}}$ are given by Eqs. (12) and (15), respectively. It follows that for a given $N_{\mathrm{Al}}^{0}$, and using $k_{\mathrm{p}}$ from $\mathrm{Al}_{2} \mathrm{O}_{3}$ thickness measurements (Table 2), $N_{\mathrm{Al}}^{\mathrm{a}}(y, t)$ only depends on $D_{\mathrm{Al}}^{\mathrm{a}}$. Equation (24) was thus fitted to the Al depletion profiles measured by EPMA after oxidation of $\mathrm{Ni}-28 \mathrm{Co}-19 \mathrm{Cr}-11 \mathrm{Al}-0.1 \mathrm{Y}$, by adjusting $D_{\mathrm{Al}}^{\mathrm{a}}$, with a least-squares method. The fitted profile is shown in Fig. 4 along with the experimental data. The procedure yielded $D_{\mathrm{Al}}^{\mathrm{a}}=1.2 \times 10^{-10} \mathrm{~cm}^{2} / \mathrm{s}$. This value was then used together with the $k_{\mathrm{p}}$ and $k^{\prime}$ from oxidation and dissolution data (Table 2) to calculate $k_{\mathrm{c}}, N_{\mathrm{Al}}^{\mathrm{m} / \mathrm{o}}$ and finally $N_{\mathrm{Al}}^{\mathrm{a}}(y, t)$ in the oxidation-dissolution regime, through Eqs. (12), (23) and (24). The resulting profile is plotted in red in Fig. 4 together with the EPMA data obtained after the $\mathrm{SiO}_{2}-\mathrm{Na}_{2} \mathrm{SO}_{4}$ exposure. The agreement is excellent, showing that the mass balance underlying the analysis of oxidation-dissolution kinetics is correct, and that using a constant, effective diffusion coefficient in the alloy is an acceptable approximation in this case.

\subsection{Application of the model: $\mathrm{Al}_{2} \mathrm{O}_{3}$-scale failure}

The analysis is now used to study the role of alloy composition in the dissolutioninduced $\mathrm{Al}_{2} \mathrm{O}_{3}$ failure. Upon exposure to $\mathrm{SiO}_{2}-\mathrm{Na}_{2} \mathrm{SO}_{4}$, two of the alloys studied underwent internal oxidation: $\mathrm{Ni}-30 \mathrm{Co}-27 \mathrm{Cr}-12 \mathrm{Al}-0.1 \mathrm{Y}\left(\gamma-13\right.$ vol. $\% \beta$ at $\left.1100{ }^{\circ} \mathrm{C}\right)$, where internal oxidation was localized, and $\mathrm{Ni}-33 \mathrm{Co}-35 \mathrm{Cr}-7 \mathrm{Al}-0.1 \mathrm{Y}$ (single-phase 
Ni-28Co-19Cr-11Al-0.1Y

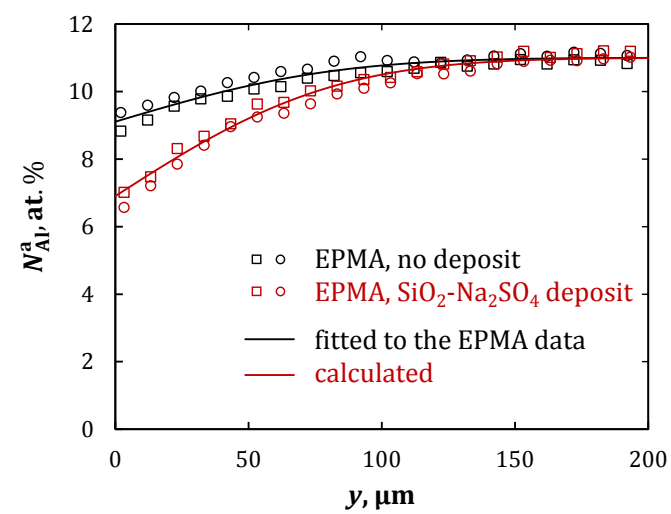

Ni-33Co-35Cr-7Al-0.1Y

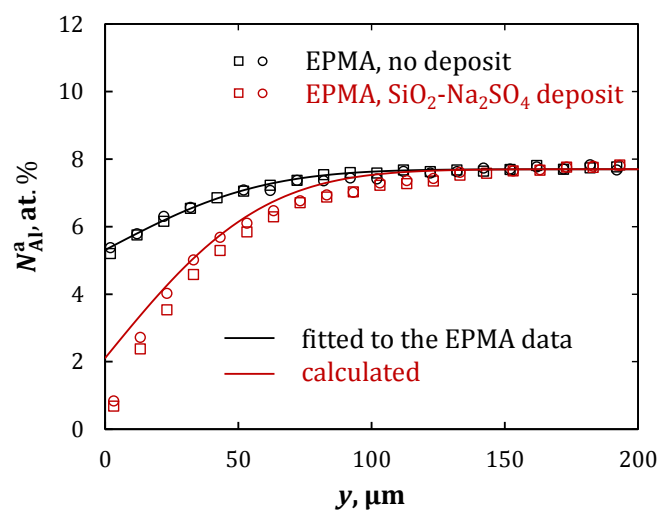

Figure 4: Aluminum concentration profiles measured by EPMA in single-phase $\gamma$ alloys oxidized with and without $\mathrm{SiO}_{2}-\mathrm{Na}_{2} \mathrm{SO}_{4}$ deposit, $50 \mathrm{~h}$ in $\mathrm{CO}_{2}-20 \mathrm{H}_{2} \mathrm{O}-1.6 \mathrm{O}_{2}$ at $1100{ }^{\circ} \mathrm{C}$ (symbols). The black lines are best fits of (24) to the deposit-free data (see text for details). The adjusted $D_{\mathrm{Al}}^{\mathrm{a}}$ were used with Eqs. (12), (23) and (24) to calculate the profiles in the oxidation-dissolution regime, plotted as red lines.

$\gamma$ at $1100{ }^{\circ} \mathrm{C}$ ), where it was nearly uniform (Fig. 3). This reflects the importance of the initial $\mathrm{Al}$ content in maintaining a sufficient $\mathrm{Al}$ flux to the metal/oxide interface. Yet the $\mathrm{Ni}-28 \mathrm{Co}-19 \mathrm{Cr}-11 \mathrm{Al}-0.1 \mathrm{Y}$ alloy studied above had a slightly lower $\mathrm{Al}$ content than that of $\mathrm{Ni}-30 \mathrm{Co}-27 \mathrm{Cr}-12 \mathrm{Al}-0.1 \mathrm{Y}$, and still maintained an external $\mathrm{Al}_{2} \mathrm{O}_{3}$ scale. This suggests that $\mathrm{Al}_{2} \mathrm{O}_{3}$-scale failure may have been favored by the high $\mathrm{Cr}$ levels in $\mathrm{Ni}-30 \mathrm{Co}-27 \mathrm{Cr}-12 \mathrm{Al}-0.1 \mathrm{Y}$ and $\mathrm{Ni}-33 \mathrm{Co}-35 \mathrm{Cr}-7 \mathrm{Al}-0.1 \mathrm{Y}$. Chromium would potentially affect the $\mathrm{Al}$ flux balance either via a reduction of $\mathrm{Al}$ diffusivity in the alloy, or via modifications of the molten silicate properties, such as its viscosity.

Chromia, like $\mathrm{Al}_{2} \mathrm{O}_{3}$, is amphoteric: depending on the silicate composition, it may behave as a basic or acidic oxide, respectively acting either as a network modifier (releasing $\mathrm{O}^{2-}$ ) or as a network former (capturing free $\mathrm{O}^{2-}$ ), which would decrease or increase the melt viscosity. At low $p_{\mathrm{O}_{2}}$, the basic form $\mathrm{CrO}$, i.e., $\mathrm{Cr}(+\mathrm{II})$, is expected to predominate. Potential effects of $\mathrm{Cr}$ oxide were studied by adding $\mathrm{Cr}_{2} \mathrm{O}_{3}$ or $\mathrm{Cr}$ to $\mathrm{Na}_{2} \mathrm{Si}_{3} \mathrm{O}_{7}$ powder (past saturation) in $\mathrm{Al}_{2} \mathrm{O}_{3}$ crucible dissolution experiments. Chromium metal was used to buffer a low $p_{\mathrm{O}_{2}}$, as would be the case if the $\mathrm{Cr}$ in an alloy reacts rapidly with a deposit. Unoxidized $\mathrm{Cr}$ particles were still present at the end of the $4 \mathrm{~h}$ exposure. An $\mathrm{Na}_{2} \mathrm{Si}_{3} \mathrm{O}_{7}-5$ wt. $\% \mathrm{CaO}$ mixture was included in the run in order to test for any effect of $\mathrm{CaO}$, which is commonly present in silicate deposits. Profiles measured by SEM-EDS after $4 \mathrm{~h}$ at $1100{ }^{\circ} \mathrm{C}$ are included in Fig. 2. No significant effect of the silicate composition was observed on either $N_{\mathrm{Al}}^{0}$ or $D_{\mathrm{Al}}^{\mathrm{NS}}-\mathrm{Al}$ did not diffuse any faster in the presence of $\mathrm{Cr}$. This should be reflected in the $\mathrm{Al}$ mass balance, which is verified by calculating $k_{\mathrm{c}}$ for alloys $\mathrm{Ni}-30 \mathrm{Co}-27 \mathrm{Cr}-12 \mathrm{Al}-0.1 \mathrm{Y}$ and $\mathrm{Ni}-33 \mathrm{Co}-35 \mathrm{Cr}-7 \mathrm{Al}-0.1 \mathrm{Y}$.

As for $\mathrm{Ni}-28 \mathrm{Co}-19 \mathrm{Cr}-11 \mathrm{Al}-0.1 \mathrm{Y}, k_{\mathrm{p}}$ values were determined from average thicknesses measured after deposit-free oxidation of each alloy. Those and the resulting $k^{\prime}$ values are included in Table 2. After exposure of $\mathrm{Ni}-30 \mathrm{Co}-27 \mathrm{Cr}-12 \mathrm{Al}-0.1 \mathrm{Y}$ and $\mathrm{Ni}-33 \mathrm{Co}-35 \mathrm{Cr}-7 \mathrm{Al}-0.1 \mathrm{Y}$ to $\mathrm{SiO}_{2}-\mathrm{Na}_{2} \mathrm{SO}_{4}$, wherever an external $\mathrm{Al}_{2} \mathrm{O}_{3}$ was still present, its thickness had significant local variations, from $\sim 0.1 \mu \mathrm{m}$ to values as 
large as those measured with no deposit (i.e., $\sim 2 \mu \mathrm{m}$ ); no meaningful average could be determined. These variations indicate that the alloys did not uniformly follow the reaction path considered in the present model, a point which will be returned to subsequently.

For the sake of simplicity, the analysis of $\mathrm{Al}$ depletion profiles is only carried out for the single-phase $\gamma$ alloy $\mathrm{Ni}-33 \mathrm{Co}-35 \mathrm{Cr}-7 \mathrm{Al}-0.1$ Y. Fitting Eq. (24) to the $\mathrm{Al}$ concentration profiles measured by EPMA after oxidation with no deposit yielded $D_{\mathrm{Al}}^{\mathrm{a}}=5.9 \times 10^{-11} \mathrm{~cm}^{2} / \mathrm{s}$. This value was then used in Eqs. (12), (23) and (24) together with the alloy $k_{\mathrm{p}}$ and $k^{\prime}$ values (Table 2) to simulate the Al profile in the dissolution-oxidation regime. The result is shown together with the corresponding experimental data in Fig. 4. The agreement is reasonable, although the shape of the simulated profile does not quite match the experimental data. This is possibly a shortcoming of using a constant, effective diffusion coefficient across such a wide composition range.

The value of $D_{\mathrm{Al}}^{\mathrm{a}}$ obtained for $\mathrm{Ni}-33 \mathrm{Co}-35 \mathrm{Cr}-7 \mathrm{Al}-0.1 \mathrm{Y}$ is about half that found for $\mathrm{Ni}-28 \mathrm{Co}-19 \mathrm{Cr}-11 \mathrm{Al}-0.1 \mathrm{Y}$ (Table 2). The difference is significant and, in addition to the lower $N_{\mathrm{Al}}^{0}$, the lower $D_{\mathrm{Al}}^{\mathrm{a}}$ contributed to reduce $N_{\mathrm{Al}}^{\mathrm{m} / \mathrm{o}}$ in $\mathrm{Ni}-33 \mathrm{Co}-35 \mathrm{Cr}-7 \mathrm{Al}-$ $0.1 \mathrm{Y}$, to the extent that it was close to zero in zones were $\mathrm{Al}_{2} \mathrm{O}_{3}$ was still present (Fig. 4). In such a situation, local fluctuations in the oxidation process, which are unavoidable in practice, would account for $\mathrm{Al}_{2} \mathrm{O}_{3}$ breakdown on the rest of the alloy surface. Yet, even if $D_{\mathrm{Al}}^{\mathrm{a}}$ tends to be lower in high $\mathrm{Cr}$ alloys, the $\mathrm{Ni}-30 \mathrm{Co}-27 \mathrm{Cr}-$ $12 \mathrm{Al}-0.1 \mathrm{Y}$ alloy had a significantly larger $\mathrm{Al}$ reservoir to start with, such that a low $D_{\mathrm{Al}}^{\mathrm{a}}$ would not, by itself, cause $\mathrm{Al}_{2} \mathrm{O}_{3}$ failure. Indeed, values of $N_{\mathrm{Al}}^{\mathrm{m} / \mathrm{o}}$ measured in zones where external $\mathrm{Al}_{2} \mathrm{O}_{3}$ was present were about 6-8 at. \% - in these zones, $\mathrm{Al}_{2} \mathrm{O}_{3}$ was far from being unstable. This in itself indicates that local $\mathrm{Al}_{2} \mathrm{O}_{3}$-scale failure on this alloy cannot be understood solely based on steady-state diffusion in the metal and the silicate. Instead, the high $\mathrm{Cr}$ concentration must have affected the transient oxidation behavior in a way that altered the initial conditions of the oxidation-dissolution process.

\section{Future Considerations}

The present analysis successfully modeled the kinetics of $\mathrm{Al}_{2} \mathrm{O}_{3}$-scale growth during concurrent oxidation and dissolution in molten $\mathrm{Na}$ silicate, despite being based on a very simple treatment of scale growth and diffusion in the alloy and the silicate. Regarding diffusion in the alloy, the rationale was that in a given alloy, the diffusivity is the same whether a deposit is present or not; this prompted the use of an effective $D_{\mathrm{Al}}^{\mathrm{a}}$ fitted to deposit-free profiles to calculate profiles in the oxidation-dissolution regime. One limitation of this method is that although the bulk composition is indeed the same, the composition range spanned in the depletion region is greater in the presence of a deposit, because of the enhanced $\mathrm{Al}$ consumption. As a consequence, the average $D_{\mathrm{Al}}^{\mathrm{a}}$ must be different, as noted above in the case of alloy $\mathrm{Ni}-33 \mathrm{Co}-35 \mathrm{Cr}-7 \mathrm{Al}-0.1 \mathrm{Y}$.

A thorough analysis would involve numerical modeling of multi-component diffusion using composition-dependent diffusion coefficients. Since the Al concentration at the alloy/scale interface depends on the $\mathrm{Al}$ flux in the alloy, it includes contributions of the $\mathrm{Cr}$ and Co concentration gradients, via off-diagonal terms of the diffusiv- 
ity matrix. Therefore, in lieu of Wagner's equations, the numerical model would have to solve the diffusion and oxidation-dissolution problems concurrently, with a finitedifference scheme such as those used by Nesbitt [13] or Nijdam et al. [14] for example. This can be extended to multi-phase alloys using a coupled thermodynamic-kinetic model [15]. Commercial programs such as Dictra [16] provide the tools for such computation, provided that the oxidation problem is implemented correctly, and that appropriate thermodynamic and mobility data are available.

As a test of the latter aspect, concentration profiles in the single-phase $\gamma$ alloys $\mathrm{Ni}-28 \mathrm{Co}-19 \mathrm{Cr}-11 \mathrm{Al}-0.1 \mathrm{Y}$ and $\mathrm{Ni}-33 \mathrm{Co}-35 \mathrm{Cr}-7 \mathrm{Al}-0.1 \mathrm{Y}$ oxidized with and without deposit were simulated in Dictra, using the experimentally measured interfacial and bulk concentrations as boundary conditions. The diffusivities were computed from the CRALDAD thermodynamic database, which was optimized for high Co and $\mathrm{Cr}$ levels in the NiCoCrAl system [17,18], and the MobNi1 [19] and NIST Ni Superalloy [20] mobility databases (both gave similar results). In all cases, the simulated profiles matched the experimental profiles less well than when using an effective $D_{\mathrm{Al}}^{\mathrm{a}}$ (the computed $\tilde{D}_{\mathrm{Al}, \mathrm{Al}}^{\mathrm{Ni}}$ values were higher than our $D_{\mathrm{Al}}^{\mathrm{a}}$ values by a factor of 10 ). The simulations improved when using the interdiffusion data by Nesbitt and Heckel [21] for $\mathrm{NiCrAl}$ alloys, despite the absence of Co in these data (it was replaced by $\mathrm{Ni}$ in our calculations). We conclude that efforts are needed to better account for the effects of high Co contents in mobility databases.

\section{Acknowledgements}

This work was supported by the Department of Energy through the University Turbine Systems Research (UTSR) Program run by the National Energy Technology Laboratory, Award Number DE-FE0007271. The authors thank Greta Lindwall (NIST, USA) and Bonnie Lindahl (CEA, France) for stimulating discussions about diffusion modeling, and for providing the mobility data and running the Dictra simulations.

\section{References}

[1] T. Gheno, G. H. Meier and B. Gleeson, High temperature reaction of MCrAlY coating compositions with $\mathrm{CaO}$ deposits, Oxidation of Metals 84 (2015) pp. 185-209. doi: 10.1007/s11085-015-9550-7.

[2] T. Gheno and B. Gleeson, Modes of deposit-induced accelerated attack of MCrAlY systems at $1100{ }^{\circ} \mathrm{C}$, Oxidation of Metals 87 (2017) pp. 249-270. doi: $10.1007 / \mathrm{s} 11085-016-9669-1$.

[3] T. Gheno and B. Gleeson, On the reaction mechanism of MCrAlY alloys with oxide-sulfate deposits at $1100{ }^{\circ} \mathrm{C}$, Oxidation of Metals 86 (2016) pp. 385-406. doi: 10.1007/s11085-016-9649-5.

[4] J. Philibert, Atom movements - Diffusion and mass transport in solids. Les Editions de Physique, Les Ulis (1991).

[5] D. Monceau and B. Pieraggi, Determination of parabolic rate constants from a local analysis of mass-gain curves, Oxidation of Metals 50 (1998) pp. 477-493. doi: 10.1023/a:1018860909826. 
[6] F. N. Rhines and R. G. Connell, Role of grain growth in the oxidation of nickel, Journal of The Electrochemical Society 124 (1977) pp. 1122-1128. doi: 10.1149/1.2133494.

[7] D. Naumenko, B. Gleeson, E. Wessel, L. Singheiser and W. J. Quadakkers, Correlation between the microstructure, growth mechanism, and growth kinetics of alumina scales on a FeCrAlY alloy, Metallurgical and Materials Transactions A 38 (2007) pp. 2974-2983. doi: 10.1007/s11661-007-9342-z.

[8] C. Wagner, Theoretical analysis of the diffusion processes determining the oxidation rate of alloys, Journal of the Electrochemical Society 99 (1952) pp. 369380. doi: 10.1149/1.2779605.

[9] Materials Preparation Center, Ames Laboratory, US DOE Basic Energy Sciences, Ames, IA, USA, available from: www.ameslab.gov/mpc.

[10] P. Wu, G. Eriksson and A. D. Pelton, Optimization of the thermodynamic properties and phase diagrams of the $\mathrm{Na}_{2} \mathrm{O}-\mathrm{SiO}_{2}$ and $\mathrm{K}_{2} \mathrm{O}-\mathrm{SiO}_{2}$ systems, Journal of the American Ceramic Society 76 (1993) pp. 2059-2064. doi: 10.1111/j.11512916.1993.tb08333.x.

[11] J. O. Bockris, J. W. Tomlinson and J. L. White, The structure of the liquid silicates: partial molar volumes and expansivities, Transactions of the Faraday Society 52 (1956) pp. 299-310. doi: 10.1039/TF9565200299.

[12] Physical constants of inorganic compounds, in CRC Handbook of Chemistry and Physics, ed. D.R. Lide, 89th ed. (CRC Press, Boca Raton, 2008), pp. 4-45.

[13] J. A. Nesbitt, Predicting minimum aluminum concentrations for protective scale formation on Ni-base alloys II. Cyclic oxidation, Journal of the Electrochemical Society 136 (1989) pp. 1518-1527. doi: 10.1149/1.2096954.

[14] T. J. Nijdam, L. P. H. Jeurgens and W. G. Sloof, Modelling the thermal oxidation of ternary alloys - compositional changes in the alloy and the development of oxide phases, Acta Materialia 51 (2003) pp. 5295-5307. doi: 10.1016/S13596454(03)00381-1.

[15] T. J. Nijdam and W. G. Sloof, Modelling of composition and phase changes in multiphase alloys due to growth of an oxide layer, Acta Materialia 56 (2008) pp. 4972-4983. doi: 10.1016/j.actamat.2008.06.010.

[16] A. Borgenstam, L. Höglund, J. Ågren and A. Engström, DICTRA, a tool for simulation of diffusional transformations in alloys, Journal of Phase Equilibria 21 (2000) pp. 269-280. doi: 10.1361/105497100770340057.

[17] T. Gheno, X. L. Liu, G. Lindwall, Z.-K. Liu and B. Gleeson, Experimental study and thermodynamic modeling of the Al-Co-Cr-Ni system, Science and Technology of Advanced Materials 16 (2015) p. 055001. doi: 10.1088/1468$6996 / 16 / 5 / 055001$.

[18] X. L. Liu, G. Lindwall, T. Gheno and Z.-K. Liu, Thermodynamic modeling of Al-Co-Cr, Al-Co-Ni, Co-Cr-Ni ternary systems towards a description for AlCo-Cr-Ni, Calphad 52 (2016) pp. 125-142. doi: 10.1016/j.calphad.2015.12.007.

[19] http://www.thermocalc.com/media/6016/dbd_mobni1_bh.pdf. accessed december 2016. 
[20] C. E. Campbell, W. J. Boettinger and U. R. Kattner, Development of a diffusion mobility database for Ni-base superalloys, Acta Materialia 50 (2002) pp. 775792. doi: 10.1016/s1359-6454(01)00383-4.

[21] J. A. Nesbitt and R. W. Heckel, Interdiffusion in Ni-rich, Ni-Cr-Al alloys at $1100{ }^{\circ} \mathrm{C}$ and $1200{ }^{\circ} \mathrm{C}$ II. Diffusion-coefficients and predicted concentration profiles, Metallurgical Transactions A-Physical Metallurgy and Materials Science 18 (1987) pp. 2075-2086. doi: 10.1007/bf02647079. 